\title{
PENGARUH TEMUAN AUDIT DAN TINDAK LANJUT REKOMENDASI HASIL PEMERIKSAAN TERHADAP OPINI ATAS LAPORAN KEUANGAN PEMERINTAH KABUPATEN/KOTA DI PRIVINSI ACEH
}

\author{
Maulidya Rahmi ${ }^{1}$, Nita Erika Ariani ${ }^{* 2}$ \\ ${ }^{1,2}$ Program Studi Akuntansi Fakultas Ekonomi Universitas Syiah Kuala \\ e-mail: maulidya.r@mhs.unsyiah.ac.id ${ }^{1}$, nea@unsyiah.ac.id ${ }^{* 2}$ \\ * Corresponding Author
}

\begin{abstract}
This study aims to determine the effect of the rest of the audit findings and follow-up of the audit results on the opinion of local government financial report of the regency/city government in Aceh Province. The population in this study is all 23 regencies/cities in Aceh Province. Samples are selected by using saturated or census sample techniques. The data source of this study cames from the secondary data obtained from the reports audit result of audi board of Indonesia for the 2015-2017 period. Analysis method used is ordinal logistic regression analysis. The results of this study indicate that the audit findings have a negative effect on opinion of local government finalcial report, and follow-up of the audit results have negative effect on opinion of local government financial report.
\end{abstract}

Keywords: Audit Findings, Follow-Up of the Audit Results, Opinion

\section{Pendahuluan}

Pemerintah daerah diwajibkan untuk menyajikan laporan keuangan atau disebut juga Laporan Keuangan Pemerintah Daerah sebagai bentuk pertanggungjawaban atau akuntabilitas dalam mengalokasikan sumber daya yang ada dalam rangka memberikan pelayanan kepada masyarakat berdasarkan prinsip tata kepemerintahan yang baik. Rakyat memberikan tuntutan yang semakin tinggi kepada penyelenggara negara atas kepercayaan yang telah diberikan dengan cara mempertanggujawabkan seluruh kegiatan yang telah dilakukan. Hal ini menyebabkan harus dilakukan pengawasan yang memadai agar pertanggungjawabab terlaksana secara maksimal..

Pemerintah daerah setiap tahun menyampaikan pertanggujawaban kepada DPRD berupa LKPD, untuk memperoleh keyakinan yang memadai atas informasi LKPD. Sebelum disampaikan kepada DPRD, LKPD harus melalui proses audit terlebih dahulu oleh Auditor eksternal yaitu BPK (Badan Pemeriksa Keuangan) (PP No. 58 Tahun 2005). BPK melakukan audit terhadap LKPD berpedoman pada Peraturan Kepala BPK RI Nomor 1 Tahun 2007 tentang Standar Pemeriksaan Keuangan Negara. Pemeriksaan keuangan yng dilakukan oleh BPK terdiri dari pemeriksaan keuangan, pemeriksaan kinerja, dan pemeriksaan dengan tujuan tertentu. Hasil dari pemeriksaan yang dilakukan BPK tersebut berupa opini, temuan audit, kesimpulan atau dalam bentuk rekomendasi. Selesai BPK melakukan pemeriksaan, maka BPK akan menerbitkan laporan baru yaitu LHP (Laporan Hasil Pemeriksaan).

LHP atas LKPD yang disusun oleh BPK memuat opini auditor BPK atas LKPD yang telah disusun oleh pemerintah daerah, sebagaimana diatur dalam Pasal 16 Undang-Undang Nomor 15 Tahun 2004. Opini yang dikeluarkan BPK biasanya memiliki hubungan yang berlawanan dengan temuan yang diperoleh auditor di lapangan. Semakin banyak temuan yang didapatkan maka akan mengakibatkan semakin tidak baik opini yang dihasilkan, begitu pula sebaliknya ketika auditor memperoleh temuan dalam jumlah yang sedikit maka akan berpengaruh kepada semakin baiknya opini yang dikeluarkan (BPK-RI, 2017). Berikut ini opini yang diperoleh oleh 23 kabupaten/kota di Provinsi Aceh selama 5 (lima) tahun terakhir: 
Tabel 1.1

Opini BPK atas Audit LKPD Pemerintah

Kabupaten/Kota Provinsi AcehTahun

2014-2018

\begin{tabular}{|c|c|c|c|c|c|}
\hline \multirow{2}{*}{ Tahun } & \multirow{2}{*}{ Pemda } & \multicolumn{4}{|c|}{ Opini } \\
\cline { 3 - 6 } & & WTP & WDP & TW & TMP \\
\hline 2014 & 23 & $13+3$ & 7 & 0 & 0 \\
& & WTP & & & \\
& & DPP & & & \\
\hline 2015 & 23 & 21 & 2 & 0 & 0 \\
\hline 2016 & 23 & 21 & 2 & 0 & 0 \\
\hline 2017 & 23 & 23 & 0 & 0 & 0 \\
\hline 2018 & 23 & 23 & 0 & 0 & 0 \\
\hline
\end{tabular}

Sumber: BPK RI Perwakilan Provinsi Aceh (2018) (bandaaceh.bpk.go.id)

Opini yang diperoleh oleh 23 kabupaten/kota di Provinsi Aceh selama 5 tahun terakhir yang diberikan oleh BPK secara keseluruhan mengalami peningkatan. Namun pada pada tahun 2016 ada dua kabupaten/kota yang mendapatkan opini WDP, padahal pada tahun 2015 kabupaten/kota tersebut menperoleh opini WTP. Kabupaten yang mengalami penurunan opini tersebut adalah Kabupaten Aceh Tenggara dan Kota Lhokseumawe.

Penyebab yang mengakibatkan penurunan opini dari dua kabupaten/kota tersebut ialah karena Pemerintah Kabupaten Aceh Tenggara gagal mempertahankan prestasi opini WTP sebagaimana opini yang diperolehnya pada tahun 2015 silam, karena berdasarkan hasil pemeriksaan BPK perwakilan Provinsi Aceh, penyebab terjadinya penurunan prestasi tersebut ialah adanya permasalahan dibidang pengelolaan zakat oleh Bendahara Pengeluaran dan Belanja Barang \& Jasa yang diserahkan kepada masyarakat serta pihak ketiga yang berindikasi adanya kecurangan atau fraud. Penyebab lainnya ialah ketidakcukupan bukti pemeriksaan yang diperoleh BPK sehingga sulit untuk menentukan nilai wajar atas saldo kas di Bendahara Pengeluaran, Aset lain, dan Belanja Barang/Jasa (BPK-RI, 2017).

Hal serupa juga terjadi pada pemerintah Kota Lhoksemawe yang mengalami pemurunan opini dari WTP di tahun 2015 menjadi WDP di tahun 2016. Penurunan opini tersebut disebabkan adanya permasalahan utang yang belum tuntas antara pemerintah kota Lhokseumawe dengan pihak ke tiga mencapai seratusan miliar rupiah. Persoalan tersebut terjadi kerena adanya kekurangan transfer DAK (Dana Alokasi Khusus) dari pemerintah pusat, sehingga utang pada pihak ketiga belum dapat dilunaskan. Untuk menyelesaikannya pihak Sekda Lhokseumawe akan mengupayakan melakukan pinjaman kepada pihak bank untuk melunasi sisa utang sebesar Rp 60 miliar (Bakri, 2017)

Persoalan yang terjadi pada dua kabupaten/kota diatas, menjadi bukti audit yang ditemukan BPK pada saat melakukan pemeriksaan di lapangan. Merujuk kepada kriteria yang harus diperhatikan Auditor, opini WTP hanya dapat diberikan kepada LKPD yang sudah memenuhi standar, seperti telah sesuai dengan SAP (Standar Akuntansi Pemerintahan), mengimplementasikan SPI (Sistem Pengendalian Intern) secara optimal \& efektif, kepatuhan terhadap perundang-undangan yang berlaku, serta kecukupan pengungkapan laporan keuangan. Keempat standar/kriteria ini belum dilaksanakan sepenuhnya oleh Kabupaten Aceh Tenggara dan Kota Lhokseumawe, sehingga BPK belum dapat memberikan opini WTP pada tahun 2016 melainkan hanya opini WDP.

Menyikapi permasalahan diatas, BPK Prov. Aceh menyampaikan bahwa untuk mendapatkan opini WTP, pemerintah kabupaten/kota tidak boleh hanya berfokus pada satu kriteria saja yaitu kesesuaian SAP, melainkan juga harus memperhatikan ketiga kriteria lainnnya, karena kriteria tersebut merupakan suatu hal yang tidak dapat dipisahkan. Adapun kriteria yang dimaksud ialah SPI, Kepatuhan perundang-undangan, dan kecukupan pengungkapan.

Efektifitas SPI dan kepatuhan terhadap perundang-undangan merupakan kriteria bagi BPK dalam memeriksa kewajaran informasi keuangan dan pemberian opini, sesuai dengan Undang-undang Nomor 15 Tahun 2004 pasal 16 ayat (1). Hal ini mengindikasikan bahwa proses pemahaman SPI memiliki peran penting dalam penentuan keputusan pemeriksaan dan pemeberian opini. Unsur-unsur pengendalian intern dalam SPI digunakan sebagai alat untuk melakukan evaluasi atas pengendalian intern pada pemerintah daerah.

Auditor juga mempertimbangkan kepatuhan terhadap perundang-undangan dalam pemberian opini. Bagi auditor dalam memberikan pendapatnya tidak hanya berpaku pada telah disajikan secara benar dan jujur serta sesuai dengan standar akuntansi saja, 
namun juga mempertimbangkan relevansi terhadap undang-undang (CPA Autralia Ltd, 2013). Karena laporan keuangan khususnya untuk pemerintahan juga harus dapat memberikan jaminan kepada pengguna laporan keuangan dan otoritas penguasa tentang pengelolaan sumber daya yang dilakukan telah memenuhi ketentuan hukum yang ditetapkan (Mardiasmo, 2002:125). Efektifitas SPI dan kepatuhan terhadap perundang-undangan ini merupakan temuan audit.

Penelitian yang dilakukan oleh Rudiansyah (2017) dengan judul Pengaruh Jumlah Temuan Audit terhadap Opini Audit Kabupaten/Kota se-Sumatera memperoleh hasil temuan atas sistem pengendalian intern dan kepatuhan terhadap peraturan perundangundangan berpengaruh negatif terhadap opini audit. Artinya temuan audit berpengaruh terhadap pemberian opini oleh BPK kepada LKPD. Laporan hasil pemeriksaan lainnya yang peroleh oleh BPK setelah melakukan pemeriksaan adalah Tindak lanjut rekomendasi pemeriksaan, yang mana juga dapat menjadi acuan auditor dalam memberikan opini. Penelitian dari Darmawati (2017) serta Kusumawati dan Ratmono (2017) menunjukkan hasil bahwa tindak lanjut rekomendasi hasil pemeriksaan berpengaruh terhadap opini audit LKPD.

Sehubungan dengan latar belakang tersebut, penelitian ini menggunakan variabel independen yang terdiri dari jumlah temuan audit atas SPI, jumlah temuan audit atas kepatuhan, tindak lanjut rekomendasi hasil pemeriksaan, dan status daerah. Oleh sebab itu, peneliti merasa tertarik untuk melaksanakan penelitian dengan judul "Pengaruh Temuan Audit dan Tindak Lanjut Rekomendasi Hasil Pemeriksaan terhadap Opini atas Laporan Keuangan Pemerintah Kabupaten/Kota di Provinsi Aceh".

\section{Tinjauan Pustaka}

\section{Laporan Keuangan Pemerintah}

Peraturan Pemerintah Nomor 24 Tahun 2005 menyebutkan "Laporan Keuangan disusun untuk menyediakan informasi yang relevan mengenai posisi keuangan dan seluruh transaksi yang dilakukan oleh suatu entitas pelaporan selama satu periode pelaporan. Secara umum kegunaan dari laporan keuangan adalah untuk membandingkan realisasi pendapatan, belanja, transfer, dan pembiayaan dengan anggaran yang telah ditetapkan, menilai kondisi keuangan, mengevaluasi efektivitas dan efisiensi suatu entitas pelaporan dan membantu menentukan ketaatannya terhadap peraturan perundang-undangan."

\section{Opini Audit}

Pasal 16 ayat (1) UU Nomor 15 Tahun 2004 tentang Pengelolaan dan tanggung Jawab Keuangan Negara menyebutkan "opini merupakan pernyataan profesional sebagai kesimpulan pemeriksa mengenai tingkat kewajaran informasi yang disajikan dalam laporan keuangan".

Kriteria yang diberikan oleh BPK yang mendasari pemberian opini adalah sebagai berikut: 1) kesesuaian dengan standar akuntansi pemerintahan (SAP); 2) kecukupan pengungkapan (adequate disclosure), 3) kepatuhan terhadap peraturan perundang-undangan, 4) efektivitas sistem pengendalian intern.

Berdasarkan Petunjuk Pelaksanaan Keuangan yang dikeluarkan BPK RI (2008), menyatakan bahwa "opini audit terbagi empat jenis, yaitu Opini Wajar Tanpa Pengecualian (WTP) atau Unqualified Opinion, Opini Wajar Dengan Pengecualian (WDP) atau Qualified Opinion, Opini Tidak Wajar (TW) atau Adverse Opinion, dan Tidak Memberikan Pendapat atau Disclaimer OpinionI".

\section{Temuan Audit}

Undang-undang No 15 Tahun 2004 tentang Pemeriksaan Pengelolaan dan Tanggung Jawab Keuangan Negara menyatakan bahwa "pemeriksaan adalah proses identifikasi masalah, analisis, dan evaluasi yang dilakukan secara independen, objektif, dan professional berdasarkan standar pemeriksaan, untuk menilai kebenaran, kecermatan, kredibilitas, dan keandalam informasi mengenai pengelolaan dan tanggung jawab keuangan negara". Pemeriksaan keuangan negara dilakukan oleh Badan Pemeriksa Keuangan (BPK) yang terdiri dari pemeriksaan keuangan, pemeriksaan kinerja, dan pemeriksaan dengan tujuan tertentu.

Undang-undang Nomor 15 Tahun 2004 menyebutkan hasil pemeriksaan BPK-RI selain opini juga dapat berupa catatan temuan, kesimpulan dan rekomendasi pemeriksaan. Laporan hasil pemriksaan BPK-RI atas temuan pemeriksaan terbagi dua, yaitu temuan atas kelemahan SPI dan temuan atas 
ketidakpatuhan terhadap peraturan perundangundangan.

\section{Tindak Lanjut Rekomendasi Hasil pemeriksaan BPK RI}

Standar Pemeriksaan Keuangan Negara (Peraturan Badan Pemeriksa Keuangan Republik Indonesia Nomor 1 Tahun 2017) menyebutkan bahwa, "Rekomendasi adalah saran dari pemeriksa berdasarkan hasil pemeriksaannya yang ditujukan kepada orang dan/atau badan yang berwenang untuk melakukan tindakan dan/atau perbaikan".

Menurut UU Nomor 15 Tahun 2004 pejabat yang memeriksa mempunyai kewajiban untuk menindaklanjuti rekomendasi BPK lengkap dengan jawaban dan penjelasan. Selanjutnya BPK menelaah jawaban tesebut untuk menentukan apakah tindak lanjut rekomendasi telah dilakukan sesuai dengan rekomendasi BPK. Hasil penelaahan diklasifikasikan dalam 4 (empat) status, yaitu: (1) tindak lanjut telah sesuai dengan rekomendasi; (2) tindak lanjut belum sesuai dengan rekomendasi; (3) rekomendasi belum ditindaklanjuti; dan (4) rekomendasi tidak dapat direkomendasi (IHPS I, 2016). Tindak lanjut tersebut dilaksanakan maksimal 60 hari setelah hasil laporan pemeriksaan diterima.

\section{Kerangka Pemikiran}

Pengaruh Temuan Audit terhadap Opini atas laporan Keuangan Pemerintah

Badan Pemeriksa Keuangan (BPK) yang bertugas melakukan pemeriksaan keuangan negara yang terdiri dari pemeriksaan keuangan, pemeriksaan kinerja, dan pemeriksaan dengan tujuan tertentu. Hasil dari pemeriksaan yang dilakukan oleh BPK tersebut berupa opini, temuan, kesimpulan dalam bentuk rekomendasi. Temuan audit BPK merupakan kasuskasus yang ditemukan terhadap laporan keuangan pemerintah atas pelanggaran yang dilakukan suatu daerah terhadap ketentuan pengendalian intern maupun terhadap ketentuan perundang-undangan yang berlaku sehingga akan berpengaruh terhadap pemberian opini oleh auditor setelah melakukan pemeriksaan. Hal ini didukung dengan hasil penelitian Munawar, dkk., (2016), Jumadi Rudiansyah (2017), Widodo dan Sudarno (2017) menyatakan temuan atas SPI dan temuan atas kepatuhan yang merupakan temuan audit berpengaruh negatif terhadap Opini LKPD.

Pengaruh Tindak Lanjut Rekomendasi Hasil pemeriksaan terhadap Opini atas laporan Keuangan Pemerintah

Pedoman pemeriksaan BPK RI mengatakan bahwa LKPD yang telah dilakukan pemeriksaan dan telah mendapatkan opini audit akan disarankan untuk segera menindaklanjuti atas setiap permasalahan yang telah menjadi rekomendasi. Tindak lanjut wajib dilakukan oleh pemerintah daerah sabagai agen dan hasus sesuai dengan rekomendasi yang diberikan. Hal ini diperlukan agar untuk periode selanjutnya tidak terjadi kesalahan yang berulang dan pengelolaan keuangan negara menjadi lebih baik.

Bagus atau tidaknya opini audit yang akan diberikan untuk LKPD pemerintah daerah juga dipengaruhi oleh jumlah tindak lanjut rekomendasi hasil pemeriksaan yang dilakukan oleh pemerintah daerah (BPK-RI, 2017). Kusumawati dan Ratmono (2017) dan Luthfina Hamidayanti (2018) keduanya memperoleh hasil yang menunjukkan bahwa tindak lanjut rekomendasi hasil pemeriksaan berpengaruh terhadapa opini audit LKPD.

\section{Hipotesis Penelitian}

H1 : Temuan audit berpengaruh terhadap opini atas laporan keuangan pemerintah kabupaten/kota di Provinsi Aceh.

H2 : Tindak lanjut rekomendasi hasil pemeriksaan berpengaruh terhadap opini atas laporan keuangan pemerintah kabupaten/kota di Provinsi Aceh.

\section{Metode Penelitian}

\section{Desain Penelitian}

Tujuan studi pada penelitian ini adalah untuk melakukan pengujian hipotesis. Jenis investigasi yang digunakan bersifat kausalitas dan data yang digunakan adalah data sekunder berupa data Laporan Hasil Pemeriksaan dan data tindak lanjut rekomendasi hasil pemeriksaan. Horizon waktu yang digunakan adalah time series dan cross sectional.situasi studi tidak diatur, unit analisis yang digunakan adalah tingkat organisasi. 


\section{Populasi dan Sampel}

Populasi dalam penelitian ini adalah pemerintah kabupaten/kota se-Aceh yang berjumlah 23 Pemerintah daerah. Sampel pada penelitian ini adalah seluruh populasi yaitu 23 Pemerintah Daerah.

Teknik pengambilan sampel yang digunakan adalah teknik sampel jenuh. Menurut Sugiyono (2012:73) sampel jenuh merupakan bagian dari jumlah dan karakteristik yang dimiliki oleh populasi, sampel yang diambil dari populasi tersebut harus dapat mewalikili (representative).

\section{Operasionalisasi Variabel}

\section{Variabel Dependen (Y)}

variabel dependen yang dipilih pada penelitian ini adalah opini atas laporan keuangan pemerintah kabupaten/kota di Aceh. Secara umum, "opini dapat didefinisikan sebagai pernyataan profesional sebagai kesimpulan pemeriksa mengenai tingkat kewajaran informasi yang disajikan dalam laporan keuangan" seperti yang diatur dalam pasal 16 ayat (1) UU Nomor 15 Tahun 2004 tentang Pengelolaan dan Tanggung Jawab Keuangan Negara yang dikeluarkan oleh BPK RI. Opini dapat diukur dengan menggunakan variabel dummy. 1 untuk opini WTP dan 0 untuk opini nonWTP (Setiawan, 2017).

\section{Variabel Independen (X) \\ Temuan Audit}

Variabel temuan audit dapat diukur dengan menggunakan formula sebagai berikut:

Temuan Audit $=($ Temuan Audit $(\mathrm{Rp}):$ Total Anggaran Belanja) x 100

(Rudiansyah, 2017)

\section{Tindak Lanjut Rekomendasi Hasil Pemeriksaan}

Variabel tindak lanjut rekomendasi hasil pemeriksaan dapat diukur dengan menggunakan formula sebagai berikut:

TLRHP = Total Rekomendasi yang diberikan BPK Tindak Lanjut sesuai dengan Rekomendasi

(Kusumawati dan Ratmono, 2017).

\section{Metode Analisis Data}

Penelitian ini bertujuan untuk menguji pengaruh temuan audit dan tindak lanjut rekomendasi hasil pemeriksaan terhadap opini atas laporan keuangan pemerintah kabupaten/kota di provinsi Aceh secara parsial. Data yang telah diperoleh akan dianalisis menggunakan metode analisis regresi logistik ordinal (Ordinal Logistic Regression) yang berguna dalam menguji pengaruh variabel bebas (independen) terhadap variabel terikat (dependen). Pengolahan data menggunakan bantuan program SPSS (Statistical Product and Service Solutions).

Formulasi analisis regresi logistic ordinal adalah sebagai berikut:

$$
\ln \left(\frac{p}{1-p}\right)=\text { B0 }+ \text { B1TA }+ \text { B2TLRHP }+\mathrm{e}
$$

Keterangan :

$$
\begin{array}{ll}
\ln \left(\frac{\mathrm{p}}{1-\mathrm{p}}\right) & : \text { opini } \\
\text { B0 } & \text { : Konstanta } \\
\text { B1 } & \text { : Koefisien } \\
\text { TA } & \text { : Temuan Audit } \\
\text { TLRHP } & \text { Tindak Lanjut Rekomendasi } \\
& \text { Hasil Pemeriksaan } \\
e & : \text { Error }
\end{array}
$$

\section{Hasil Dan Pembahasan \\ Analisis Statistik Deskriptif}

Analisis Statistik Deskriptif merupakan langkah awal dalam melakukan pengujian variabel. Analisis ini dilakukan untuk melihat nilai minimum, maksimum, mean, dan standar deviasi dari keseluruhan data sampel yang digunakan dalam penelitian. Variabel yang akan dilihat dalam penelitian ini adalah variabel dependen berupa opini atas laporan keuangan pemerintah daerah dan variabel independen berupa temuan audit dan tindak lanjut rekomendasi hasil pemeriksaan.

Tabel 4.1

Hasil Analisis Statistik Deskriptif Descriptive Statistics

\begin{tabular}{|l|r|r|r|r|r|}
\hline & & & \multicolumn{1}{|c|}{ Descriptive Statistics } & \multicolumn{1}{c|}{$\begin{array}{c}\text { Std. } \\
\text { Deviation }\end{array}$} \\
\hline Opini & 69 & .0 & 1.0 & .870 & .3392 \\
TA & 69 & .0 & 3.54 & .28 & .6847 \\
TLRHP & 69 & .00 & 48.00 & 12.50 & 8.9732 \\
Valid N & 69 & & & & \\
(listwise) & & & & \\
\hline
\end{tabular}

Sumber: Output SPSS 22, 2019 


\section{Uji Goodness of Fit}

Tabel 4.2

Hasil Uji Goodness of Fit

Hosmer and Lemeshow Test

\begin{tabular}{|l|r|r|r|}
\hline Step & Chi-square & \multicolumn{1}{|c|}{ df } & \multicolumn{1}{c|}{ Sig. } \\
\hline 1 & 6.739 & 8 & .565 \\
\hline
\end{tabular}

Sumber: Output SPSS 22, 2020

Tabel 4.2 menunjukkan bahwa nilai Chisquare sebesar 6,739 dengan signifikansi sebesar 0,565 . Berdasarkan hasil tersebut dapat disimpulkan bahwa model dapat dikatakan fit karena nilai signifikansi lebih besar dari $5 \%(0,565>0,05)$.

\section{Uji Cox and Snell's $R$ Square dan Nagellkerke's $R$} Square

Tabel 4.3

Uji Cox and Snell's R Square dan Nagellkerke's $R$ Square

Model Summary

\begin{tabular}{|l|r|r|r|}
\hline Step & -2 Log likelihood & $\begin{array}{c}\text { Cox \& Snell R } \\
\text { Square }\end{array}$ & $\begin{array}{c}\text { Nagelkerke R } \\
\text { Square }\end{array}$ \\
\hline 1 & $27.882^{\mathrm{a}}$ & .309 & .574 \\
\hline
\end{tabular}

a. Estimation terminated at iteration number 7 because parameter estimates changed by less than .001 .

Sumber: Output SPSS 22, 2020

Berdasarkan Tabel 4.3 , besar nilai koefisien determinasi Cox and Snell's $R$ Square dan Nagellkerke's $R$ Square berturut-turut sebesar 0,309 dan 0,574 yang berarti variabel dependen (opini atas laporan keuangan pemerintah) dijelaskan oleh variabel independen (temuan audit dan tindak lanjut rekomendasi hasil pemeriksaan). Namun variabelvariabel tersebut memberikan penjelasan terbatas dalam memprediksi variabel dependen karena nilai 0,574 atau $57,4 \%$ masih lumayan jauh angka 1

\section{Tabel Matriks Klasifikasi}

Tabel 4.4

Tabel Matriks Klasifikasi

Classification Table

\begin{tabular}{|c|c|c|c|c|c|}
\hline & \multirow{3}{*}{\multicolumn{2}{|c|}{ Observed }} & \multicolumn{3}{|c|}{ Predicted } \\
\hline & & & \multicolumn{2}{|c|}{ Opini } & \multirow{2}{*}{$\begin{array}{c}\text { Percentage } \\
\text { Correct }\end{array}$} \\
\hline & & & Non-WTP & WTP & \\
\hline \multirow[t]{3}{*}{ Step 1} & Opini & Non-WTP & 5 & 4 & 55.6 \\
\hline & & WTP & 0 & 60 & 100.0 \\
\hline & Over: & ercentage & & & 94.2 \\
\hline
\end{tabular}

a. The cut value is .500

Sumber: Output SPSS 22, 2020
Tabel 4.4 menunjukkan bahwa jumlah pemerintah daerah yang diprediksi menerima opini non-WTP sebanyak 5 pemerintah daerah, sedangkan berdasarkan data pengamatan, pemerintah daerah yang mendapatkan opini non-WTP sebanyak 9 pemerintah daerah. Sehingga, nilai kekuatan prediksi pemerintah daearah yang mendapatkan opini non-WTP sebesar $55,6 \%$. Tabel diatas juga menunjukkan bahwa jumlah pemerintah daerah yang diprediksi menerima opini WTP sebanyak 60 pemerintah daerah sama berdasarkan data pengamatan, sehingga nilai kuatan prediksi pemerintah daerah yang mendapatkan opini WTP sebesar $100 \%$.

\section{Analisis Regresi Logistik}

Tabel 4.5

Analisis Regresi Logistik

Variables in the Equation

\begin{tabular}{|c|c|c|c|c|c|c|c|}
\hline & & B & S.E. & Wald & df & Sig. & $\begin{array}{c}\operatorname{Exp}( \\
\text { B) }\end{array}$ \\
\hline \multirow{3}{*}{$\begin{array}{l}\text { Step } \\
1^{\text {a }}\end{array}$} & TA & -5.252 & 2.027 & 6.715 & 1 & .010 & .005 \\
\hline & $\begin{array}{l}\text { TLRH } \\
\mathrm{P}\end{array}$ & -.037 & .053 & .477 & 1 & .490 & .964 \\
\hline & $\begin{array}{l}\text { Consta } \\
\text { nt }\end{array}$ & 4.049 & 1.125 & 12.951 & 1 & .000 & $\begin{array}{r}57.33 \\
0\end{array}$ \\
\hline
\end{tabular}

a. Variable(s) entered on step 1: TA, TLRHP.

Sumber: Output SPSS 22, 2019

Berdasarkan Tabel 4.5, diperoleh hasil pengujian pada koefisien regresi sebagai berikut:

Opini $=4.049-5,252 \mathrm{TA}-0,037 \mathrm{TLRHP}+\mathrm{e}$

\section{Pembahasan}

Pengaruh Temuan Audit terhadap Opini atas laporan Keuangan Pemerintah

Hasil penelitian menggunakan regresi logistik ordinal menunjukkan bahwa temuan audit berpengaruh negatif terhadap opini atas laporan keuangan kabupaten/kota di Provinsi Aceh. Dilihat dari nilai koefisien regresi sebesar -5,252 dan berarah negatif, berarti variabel independen ini berhubungan dengan varibel dependen yaitu opini atas laporan keuangan pemerintah secara negatif. Artinya apabila temuan audit yang ditemukan sedikit maka opini yang diperoleh akan semakin baik, begitu juga dengan sebaliknya apabila semakin banyak temuan audit yang diperoleh auditor maka kualitas opini yang didapatkan akan semakin menurun. Temuan audit merupakan hasil dari suatu audit, bentuk temuan menggabungkan 
semua informasi penting yang berkaitan dengan suatu masalah audit tertentu berupa, misalnya, pengendalian yang tidak berfungsi, salah saji potensial dalam laporan keuangan atau adanya ketidakefisienan yang menonjol (Bastian, 2018).

Hasil penelitian ini sejalan dengan penelitian yang dilakukan oleh Munawar., dkk (2016). Penelitian Munawar., dkk (2016) menemukan bahwa temuan SPI dan temuan kepatuhan yang keduanya merupakan temuan audit berpengaruh negatif terhadap opini atas LKPD. Artinya bahwa apabila SPI suatu entitas semakin baik maka jumlah temuan audit akan semakin kecil dan opini atas LKPD yang diperoleh akan baik dan apabilaBPK menemukan adanya ketidakpatuhan terhadap peraturan perundang-undangan akan mengakibatkan penilaian kinerja pengelolaan daerah tidak baik dan opini atas LKPD tidak WTP.

\section{Pengaruh Tindak Lanjut Rekomendasi Hasil pemeriksaan terhadap Opini atas laporan Keuangan Pemerintah}

Hasil penelitian menggunakan regresi logistik ordinal menunjukkan bahwa variabel tindak lanjut rekomendasi hasil pemeriksaan berpengaruh negatif terhadap opini atas laporan keuangan pemerintah. Dilihat dari hasil pengujian nilai koefisien regresi sebesar -0,037 yang berarah negatif, berarti variabel independen ini berhubungan dengan varibel dependen yaitu opini atas laporan keuangan pemerintah secara negatif. Artinya apabila selisih antara total rekomendasi yang diberikan oleh BPK dengan tindak lanjut yang sesuai dengan rekomendasi yang telah dilakukan oleh pemerintah daerah semakin besar maka berdampak pada penerimaan opini yang lebih rendah, dan juga sebaliknya apabila semakin kecil jumlah selisih rekomendasi yang didapatkan maka akan semakin bagus kualitas opini yang diterima. Namun nilai koefisien regresi yang sebesar -0,037 atau sebesar $3.7 \%$, menunjukkan pengaruh yang kecil berarti variabel tindak lanjut rekomendasi hasil pemeriksaan tidak terlalu mempengaruhi variabel opini.

Hasil penelitian ini sejalan dengan penelitian yang dilakukan oleh Hamidayanti (2018). Dalam penelitian Hamidayanti (2018) hasil yang diperoleh atas pengujian variabel tindak lanjut rekomendasi hasil pemeriksaan adalah berpengaruh terhadap opini audit laporan keuangan pemerintah daerah. Jumlah tindak lanjut yang dilakukan suatu pemerintah daerah mencerminkan baik tidaknya pengelolaan keuangan suatu pemerintah daerah yang dapat dilihat dari baik tidaknya laporan keuangan pemerintah daerah. Sehingga dapat disimpulkan bahwa jumlah tindak lanjut yang dilakukan oleh pemerintah daerah atas rekomendasi yang diberikan oleh BPK dapat mencerminkan baik tidaknya pengelolaan keuangan suatu pemerintah daerah yang dinilai dari opini laporan keuangan pemerintah daerah.

\section{Kesimpulan, Keterbatasan dan Saran Kesimpulan}

Kesimpulan hasil pembahasan penelitian di atas, yaitu sebagai berikut:

1. Temuan audit berpengaruh negatif terhadap opini atas laporan keuangan pemerintah kabupaten/kota di Provinsi Aceh.

2. Tindak lanjut rekomendasi hasil pemeriksaan berpengaruh negatif terhadap opini atas laporan keuangan pemerintah kabupaten/kota di Provinsi Aceh.

\section{Keterbatasan Penelitian}

Penelitian ini memiliki keterbatasan yang dapat dipertimbangkan pada penelitian selanjutnya sehingga diperoleh hasil yang lebih baik lagi di masa mendatang, adapun keterbatasannya adalah sebagai berikut:

1. Penelitian ini hanya menggunakan dua variabel independen. Kedua variabel independenden yang digunakan dalam penelitian ini kurang dapat menjelasakan secara keseluruhan faktor-faktor yang mempengaruhi variabel dependen.

2. Tahun pengamatan dalam penelitian ini hanya 3 tahun, yaitu tahun 2015-2017.

\section{Saran}

Berdasarkan hasil analisis pembahasan, kesimpulan, dan keterbatasan pada penelitian ini yang telah ditemukan sebelumnya, terdapat beberapa saran yang dapat diberikan antara lain sebagai berikut:

1. Bagi peneliti selanjunya diharapkan untuk menambah variabel independen lainnya yang dapat menjelasakan variabel dependen dengan lebih baik.

2. Bagi peneliti selanjunya diharapkan untuk menambah tahun pengamatan untuk penelitian agar hasil yang diperoleh lebih baik. 


\section{Daftar Pustaka}

Badjuri, Achmad., dan Elisa Trihapsari. (2004), Audit Kinerja Pada Sektor Publik Pemerintah. Fokus Ekonomi. 3(2).

Bakri. (2017). Pemko Gagal Pertahankan WTP. Diakses pada tanggal 5 November 2019. Melalui

https://www.google.com/amp/s/aceh.tribunnews .com/amp /2017/10/02/pemko-gagalpertahankan-wtp.

BPK RI Perwakilan Provinsi Aceh. (2017). Kabupaten Aceh Tenggara Gagal Pertahankan Opini WTP. Diakses pada tanggal 5 November 2019. Melalui http://bandaaceh.bpk.go.id/?p=11371.

Badan Pemeriksa Keuangan Republik Indonesia. (2019). Daftar Opini Laporan Keuangan Pemerintah Daerah Tahun 2009 S.D 2018. Diakses pada tanggal 14 September 2019. Melalui https://bandaaceh.bpk.go.id/wpcontent/uploads/2019/07/Whats App-Image2019-07-31-at-09.39.03.jpeg

Badan Pemeriksa Keuangan Republik Indonesia. (2017). Ikhtisar Hasil Pemeriksaan Semester (IHPS) I Tahun 2017. Diakses pada tanggal 5 November 2019. Melalui http://www.bpk.go.id/assets/files/ihps/2017/I/ih psi20171507002855. pdf.

Badan Pusat Statistik Provinsi Aceh. (2015). Namanama Ibukota Kabupaten/Kota di Provinsi Aceh. Diakses pada tanggal 14 Oktober 2019. Melalui www.aceh.bps.go.id.

Bastian, Indra. (2018). Audit Sektor Publik Pemeriksaan Pertanggungjawaban Pemerintah. Jakarta: Salemba Empat.

Cooper, Donald R., \& Pamela, S. Schindler. (2006). Metode Riset Bisnis, Volume 1. Jakarta: PT Media Global Edukasi.

Darmawati. (2017). Pengaruh Kelemahan Sistem Pengendalian Internal, Ketidakpatuhan terhadap Perundang-Undangan, dan Tindak Lanjut Rekomendasi Hasil Pemeriksaan terhadap Opini BPK RI. Fakultas Ekonomi dan Bisnis Universitas Lampung.
Erlina dan Rasdianto. (2013). Akuntansi Keuangan Daerah Berbasis Akrual. Medan: Brama Ardian.

Ghozali, Imam. (2013). Aplikasi analisis multivariate dengan program IBM SPSS 21. Semarang: UNDIP.

Hall, James. (2007). Sistem Informasi Akuntansi. Terjemahan Dewi Fitriasari. Salemba Empat: Jakarta.

Hamidayanti, Luthfina. (2018). Faktor-faktor yang Menpengaruhi Opini Audit Laporan Keuangan Pemerintah Daerah. Institut Agama Islam Negeri Surakarta.

Indriantoro, N., \& B. Supomo. (2014). Metodologi Penelitian Bisnis Untuk Akuntansi dan Manajemen, Edisi Pertama. Yogyakarta: BPFE.

Johnson, L.E., S. Lowenson, dan J.L. Reck, S.P. Davies. (2012) "Management Letter Comment: Their Determinants and Their Association with Financial Reporting Quality In Local Government". Journal Account Public Policy $31,575-592$.

Kuncoro, M. (2013). Metode Riset untuk Bisnis dan Ekonomi. Jakarta: Penerbit Erlangga.

Kusumawati, D., dan Ratmono, D. (2017). Determinan opini atas laporan keuangan pemerintah daerah di Indonesia. Diponegoro Journal of Accounting, 6(1), 1-15.

Mardiasmo. (2002). Otonomi dan Manajemen Keuangan Daerah. Yogyakarta: Andi.

Mulyadi dan Kanaka Puradiredja. (1998), Auditing, Edisi Kelima, Buku Satu. Jakarta: Salemba Empat.

Munawar, Nadirsyah, dan Syukriy Abdullah. (2016). Pengaruh Jumlah Temuan Audit atas Spi dan Jumlah Temuan Audit atas Kepatuhan terhadap Opini atas Laporan Keuangan Pemerintah Kabupaten/Kota di Aceh. Jurnal Magister Akuntansi Pascasarjana Universitas Syiah Kuala. 5(2), 57-67.

Murwanto, dkk., (2012). Audit Sektor Publik Suatu Pengantar Bagi Pembangunan Akuntabilitas Instansi Pemerintah. LPKPAP. 
Mustikasini, Widya Astuti dan Fitriasari. (2012) Pengeruh Karakteristik Pemerintah Daerah dan Temuan Audit BPK terhadap Kinerja Pemerintah Dearah Kabupaten/Kota di Indonesia Tahun Anggaran 2007. Forum: Simposium Nasional Akuntansi 15.

Pernyataan Standar Akuntansi Pemerintah (PSAP) Nomor 01 Paragraf 14 SAP tentang Penyajian Laporan Keuangan dalam lampiran Peraturan Pemerintah Nomor 71 Tahun 2010.

Pernyataan Standar Akuntansi Keuangan (PSAK). (2006). Tim Sukses UKT Akuntansi.

Republik Indonesia. Peraturan Badan Pemeriksa Keuangan Nomor 1 Tahun 2017 tentang Standar Pemeriksaan Keuangan Negara $(S P K N)$.

Peraturan Pemerintah Nomor 58

Tahun 2005 tentang Pengelolaan Keuangan Daerah.

\section{Peraturan Badan Pemeriksa}

Keuangan Nomor 2 Tahun 2017 tentang Pementauan Pelaksanaan Tindak Lanjut Rekomendasi Hasil Pemeriksaan Badan Pemeriksa Keuangan.

. Peraturan Menteri dalam Negeri Nomor 4 Tahun 2008 tentang Pedoman Pelaksanaan Reviu atas Laporan Keuangan Pemerintah Daerah.

Peraturan Pemerintah Nomor 8

Tahun 2006 tentang Pelaporan Keuangan dan Kinerja Instansi Pemerintah

. Peraturan Pemerintah Nomor 24

Tahun 2005 tentang Standar Akuntansi Pemerintahan.

. Peraturan Pemerintah Nomor 71

Tahun 2010 tentang Standar Akuntansi Pemerintahan.

. Undang-Undang Dasar Negara Republik Indonesia Tahun 1945.

\section{Undang-Undang Nomor 15}

Tahun 2004 tentang Pemeriksaan Pengelolaan dan Tanggung Jawab Keuangan Negara.
- Undang-Undang Nomor 15 Tahun 2006 Tentang Badan Pemeriksa Keuangan.

Undang-Undang Nomor 17

Tahun 2003 tentang Keuangan Negara. Undang-Undang Nomor 23 Tahun 2014 tentang Pemerintah Daerah.

Rudiansyah. (2017). Pengaruh Jumlah Temuan Audit terhadap Opini Audit Kabupaten/Kota SeSumatera. Program Magister Ilmu Akuntansi Fakultas Ekonomi dan Bisnis Universitas Lampung.

Rosadi, Samsul., Yudi Siyamto dan Helty Nur Aisyah. (2017). Pengaruh Ketepatan Waktu Penyampaian Laporan Keuangan, Kelemahan Sistem Pengendalian Internal, Kepatuhan Peraturan Perundang-Undangan, Status Daerah dan Ukuran Daerah terhadap Opini Laporan Keuangan Pemerintah Daerah di Pulau Jawa Tahun 2013. Jurnal Ilmiah Ekonomi Islam. 3(4), 99-111.

Safitri, Ni Luh K. S. A., dan Darsono. (2015). Pengaruh Sistem Pengendalian Internal dan Temuan Kepatuhan Terhadap Opini Audit pada Pemerintah Daerah. Diponegoro Journal of Accounting, 5(1), 1-12.

Sugiyono. (2007). Metode Penelitian Bisnis. Bandung: Alfabeta.

Sekaran, Uma., dan Roger Bougie. (2017). Metode Penelitian Untuk Bisnis. Jakarta: Salemba Empat.

Sanusi, A. (2011). Metodologi Penelitian Bisnis. Jakarta: Salemba Empat.

Sipahutar, Hottua dan Siti Khairani. (2013). Analisis Perubahan Opini LHP BPK RI atas Laporan Keuangan Pemerintah Daerah Kabupaten Empat Lawang.

Setiawan, R. A. (2017). Pengaruh sistem pengendalian intern dan kepatuhan pada peraturan perundangundangan terhadap opini laporan keuangan pemerintah daerah. Skripsi tidak diterbitkan, Departemen Akuntansi Fakultas Ekonomi dan Bisnis Universitas Hasanuddin, Makassar. 